\title{
S. J. Wellensiek
}

Susan Jacobus Wellensiek was born in Amsterdam on 8 March 1899. In 1917 he went to Wageningen to study at the college that was to become in the following year the Agricultural University. He was a brillant student, who passed all examinations with honours. In 1922 he obtained the degree of 'landbouwkundig ingenieur' (master of agricultural science) and became a research assistant at the Laboratory of Plant Pathology. Two years later he took the degree of Doctor of Agricultural Science (with honours). His thesis dealt with 'Factors affecting the formation of blind tubers in early potatoes'. It was written in Dutch, but subsequently translated into English, German and Czech. Also in 1924 the Senate of the Agricultural University awarded the first prize, a gold medal, to his Genetic Monograph of Pisum, which was an answer to a prize question put by the Senate.

For eight years, from 1922 to 1929, Wellensiek was attached to the Laboratory of Plant Pathology (then called the Laboratory for Mycology and Potato Research) of which H. M. Quanjer was the director. During this time he worked on potato diseases, disease resistance and a few other subjects. Meanwhile, however, he continued his genetical work on peas, and added 15 titles to his long list of publications on this subject. The beech trees in front of the laboratory gave him inspiration for two papers on phenology. During the academic year 1926-1927 he worked at the University of Minnesota at St. Paul, USA, a stay financed by a Rockefeller Foundation fellowship. In 1930 Wellensiek departed for Java, where for eight years he was attached to the Research Station West Java at Bogor. Here he worked as a selectionist for tea and cacao. In a characteristic manner, he first oriented himself in the broadest way on what should be done, and then set about to realize a programme in very diverse fields. Among the subjects he studied were yield determination, the effect of the environment on yield, selection of mother trees and propagation by cuttings and buddings. His most important results are to be found in a series of four papers entitled 'Researches on quantitative tea selection'. In cacao, similar work was done although on a smaller scale. Papers on vernalization and colchicine show that he was keeping abreast of all important developments both in the field of plant growing and that of plant breeding. Essays on 'Causality and chance', and on 'Freedom of will regarded from a genetical viewpoint' show his interest in fundamental problems. During this period he also wrote his four papers on the technique of scientific publication, a subject of perennial interest to him.

On his way to Holland on leave in August 1936 he travelled in the Phillippines, China and Japan and revisited the USA. On his way back to Java he spent six weeks studying tea cultivation and tea selection in India and Ceylon at the request of the Government of the Dutch East Indies.

In 1938 Wellensiek returned to Holland and to Wageningen, where he joined the staff of the Institute for Plant Breeding, which was then led by C. Broekema. Here he applied to rye the insight into breeding problems gained with the tea plant. $\mathrm{He}$ published papers on yield analysis, colchicine treatments, vegetative propagation and intergeneric hybridization. Meanwhile he resumed his genetical work with peas, which he continues to the present day.

In the war years he wrote his book 'Fundamentals of plant breeding' (ir Dutch, with 
some chapters by other authors). The first edition, published in 1943, was soon out of print, and so was a second edition, which appeared in 1947.

Having worked for eight years at the Institute for Plant Breeding, Wellensiek was appointed extraordinary professor in horticulture on 1 February 1946. On 1 October 1947 he became ordinary professor and took over the direction of the Laboratory of Horticulture from A. M. Sprenger. His inaugural address 'The pursuit of happiness' once again showed his interest in fundamental problems.

In 1947, the department of horticulture was very much as it had been in 1923, when the main building was finished. Sprenger's work in the field of storage and preservation of horticultural produce had led to the founding of a separate institute, and his energetic efforts to develop the remaining department had been frustrated first by the economic conditions of the thirties and then by the devastation of the war. Wellensiek, after having obtained a clear view of the function of the Laboratory in the whole of the horticultural research in the Netherlands, resolved to concentrate on some general problems connected with both growing and breeding, in a way that may be broadly characterized as 'basic horticultural research'.

His research on problems of plant growing was centered around the process of flowering, particularly as influenced by daylength and vernalization. His many papers on the subject deal with such diverse topics as the juvenile phase, during which the plant cannot be induced to flower, the inhibitory effect of light in short-day plants, the relation between stem elongation and flowering in rosette plants, and the relation between flowering responses to short day, long day, temperature and gibberellic acid in plants that respond to several or all of these stimuli, like his favourite object of study, Silene armeria. In Campanula medium, he was able to show that the plant flowers after having been subjected either to low temperature followed by long days, or to short days followed by long days. In Lunaria and chicory, he found that dividing cells are the locus of the action of low temperature with regard to flowering. A recent discovery was that transfer of a flowering stimulus occurs in graft combinations between the short day plant Xanthium (Compositae) and the long day plant Silene (Caryophyllaceae).

In the field of plant breeding, he worked mainly with peas and Cyclamen, although he also published on apple and asparagus. In peas, he continued his linkage studies, but he also studied the genetics of flower colours, and particularly of artificially induced mutants. In recent years, this research was concentrated mainly on the pea mutant 'stringless' and on various early-flowering mutants. Particular attention was paid to the effect of the environment on the expression of these characteristics.

Wellensiek had a great influence on his pupils. His courses for undergraduate students were summarized in his book 'Fundamentals of horticultural plant production' (in Dutch, 1956), written in collaboration with J. Doorenbos. He concentrated his attention, however, on graduate and post-graduate students, which he formed into independent research workers in an inimitable way. Under his guidance no less than 35 students took the degree of Doctor of Agricultural Science.

Under his direction, the Laboratory of Horticulture developed rapidly. The trial grounds expanded from 7 to 13 hectares. Instead of the few decrepit greenhouses left after the war there is now an area of 1 hectare of modern structures. In December 1963 a large phytotron became operative, and in 1965 the department moved into a new building, giving adequate facilities to a staff that has expanded to 76 people. In the 22 years of his directorate, the Laboratory of Horticulture published 242 scientific papers, of which 77 were written by Wellensiek himself. 
It is impossible to enumerate all the committees on which Wellensiek has served to promote scientific research, particularly in the field of horticulture. It should be mentioned, however, that in 1955 he was president of the XIVth International Horticultural Congress held at Scheveningen, the admirable organization of which has been exemplary to later congresses. At this occasion, the International Society of Horticultural Science was founded at his initiative. Of his many subsequent functions the most important is that of deputy-chairman of the Board of the Netherlands Organization for Pure Scientific Research.

Wellensiek was elected a member of the Royal Netherlands Academy of Science in 1950 , being the first and so far the only Wageningen graduate to receive this honour. In 1958 he was elected a member of the Académie d'Agriculture de France, and in 1967 he became a foreign member of the Royal Flemish Academy of Science of Belgium. In September 1959 he received the honorary degree of Doctor of Agriculture from the Agricultural College of Norway, and in 1964 the Technical University at Hannover bestowed the same honour upon him.

Of course for a man of Wellensiek's energy the relief from his official function will only mean that he will double his efforts in other fields. A number of postgraduate students is still preparing doctor's theses under his guidance, and the staff of the Laboratory of Horticulture hopes to have him in their midst as a honorary research worker for many years to come. At this moment, he is very actively engaged in research on flowering of Silene and on various genetical and physiological problems in the pea. One may still look forward to many important contributions to horticultural science, and it is certain that many of his friends and collaborators will often seek his valuable advice.

J. Doorenbos 